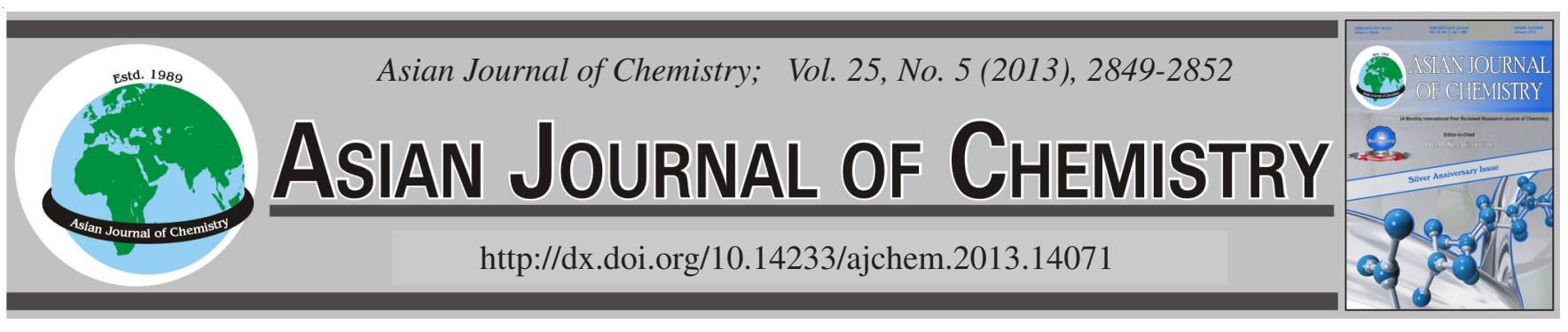

\title{
Removal of Fluorine from the Waste Acid of Lead Smelter
}

\author{
JiAYUAN Li ${ }^{1,2, *}$, TIANZU YANG ${ }^{1}$ and ZhaOAN ZHOU ${ }^{1}$
}

${ }^{1}$ School of Metallurgical Science and Engineering, Central South University, Changsha 410083, P.R. China

${ }^{2}$ Department of Chemical Engineering and Life Science, Xiangnan University, Chenzhou 423000, P.R. China

*Corresponding author: Tel: +86 731 88836791; E-mail: lijiayuanchen@yahoo.com.cn

(Received: 19 May 2012;

Accepted: 26 November 2012)

AJC-12467

Based on thermodynamic data, using lead ions to remove the fluoride in the waste acid solution was studied. Lead-fluoride ion-water system E-log $\left[\mathrm{F}^{-}\right]$diagram and the solubility curve of lead fluoride was drawn at $25^{\circ} \mathrm{C}$. When lead oxide or the other materials such as the lead blast furnace dust and lead ash were used as the precipitant, the removal rate of fluoride is more than $90 \%$ under proper conditions in the waste acid solution.

Key Words: Lead fluoride, Lead-fluoride ion-water system, Thermodynamics, Waste acid.

\section{INTRODUCTION}

In recent years, with the sharp increase of the production capacity of non-ferrous smelting industry, a large number of fluoride, chloride and heavy metal ions transferred to the smelting flue gas in the process of roasting, smelting and blowing. Acid making with flue gas process will produce a lot of waste acid in smelters. The waste acid contains large amounts of fluoride, chloride, sulfate and heavy metal ions, which has been recognized as one of the major problems smelting industry. This imposes a serious threat to human health and environmental issues. Thus, a renewed interest in the ions removal from industrial wastewaters has been greatly increased $^{1-6}$. Removal of fluorine is an unavoidable problem to cyclic utilization and standard discharge of waste acid. At present, lime precipitation treatment is still widely used as an important method $^{7-9}$. Additionally, electrodialysis ${ }^{10-12}$, sorption $^{13-16}$, ion exchange resins ${ }^{17-20}$ and membrane technology ${ }^{21-25}$ have been reported.

Lime method is low cost, but it will generate a lot of waste residue, inconvenience of subsequent disposal and results in second pollution. Electric flocculation and ion exchange method are difficult to deal with the high concentration of fluoride and result in high energy consumption, more processing costs. According to the above finding and requirements of the handling of waste acid in smelter, we make use of materials containing rich lead oxide which come from smelter production process as defluoridation reagents. This paper mainly makes a theoretical analysis of the fluoride removal from waste acid based on smelter rich lead oxide materials, which is of great significance for the smelter waste acid treatment.

Theoretical analysis: The complex formation reactions of lead ion with fluoride ion in the lead-fluoride ion-water system are shown as follows:

$$
\begin{gathered}
\mathrm{Pb}^{2+}+\mathrm{F}^{-}=\mathrm{PbF}^{+} ; \mathrm{K}_{1}=\frac{\left[\mathrm{PbF}^{+}\right]}{\left[\mathrm{Pb}^{2+}\right]\left[\mathrm{F}^{-}\right]} \\
\mathrm{Pb}^{2+}+2 \mathrm{~F}^{-}=\mathrm{PbF}_{2(\mathrm{aq})} ; \mathrm{K}_{2}=\frac{\left[\mathrm{PbF}_{2}\right]}{\left[\mathrm{Pb}^{2+}\right]\left[\mathrm{F}^{-}\right]^{2}} \\
\mathrm{~Pb}^{2+}+3 \mathrm{~F}^{-}=\mathrm{PbF}_{3}^{-} ; \mathrm{K}_{3}=\frac{\left[\mathrm{PbF}_{3}^{-}\right]}{\left[\mathrm{Pb}^{2+}\right]\left[\mathrm{F}^{-}\right]^{3}} \\
\mathrm{~Pb}^{2+}+4 \mathrm{~F}^{-}=\mathrm{PbF}_{4}^{2-} ; \mathrm{K}_{4}=\frac{\left[\mathrm{PbF}_{3}^{2-}\right]}{\left[\mathrm{Pb}^{2+}\right]\left[\mathrm{F}^{-}\right]^{4}}
\end{gathered}
$$

where $\mathrm{K}_{1}, \mathrm{~K}_{2}, \mathrm{~K}_{3}, \mathrm{~K}_{4}$ are the concentration equilibrium constants referred to a given temperature and a fixed ionic strength. These equilibrium constants at a ionic strength $(\mathrm{I}=1)$ and $25^{\circ} \mathrm{C}$ is shown in Table- $1^{26}$.

\begin{tabular}{ccccc}
\multicolumn{5}{c}{ TABLE-1 } \\
\multicolumn{5}{c}{$\begin{array}{c}\text { EQUILIBRIUM CONSTANTS OF LEAD AND } \\
\text { FLUORIDE COMPLEX ION IN SOLUTION }\end{array}$} \\
\hline Complex & $\log \mathrm{K}_{1}$ & $\log \mathrm{K}_{2}$ & $\log \mathrm{K}_{3}$ & $\log \mathrm{K}_{4}$ \\
\hline $\mathrm{Pb}^{2+}-\mathrm{F}^{-}$ & 1.44 & 2.54 & 3.42 & 3.08 \\
\hline
\end{tabular}

From the above complex formation reaction and the equilibrium constants, the relation of the total lead concentration 
$\left[\mathrm{Pb}^{2+}\right]_{\mathrm{T}}$ with the equilibrium concentration of uncomplexed lead ion $\left[\mathrm{Pb}^{2+}\right]$ can be represented by:

$$
\begin{gathered}
{[\mathrm{Pb}]_{\mathrm{T}}=\left[\mathrm{Pb}^{2+}\right]+\left[\mathrm{PbF}^{+}\right]+\left[\mathrm{PbF}_{2}\right]+\left[\mathrm{PbF}_{3}^{-}\right]+\left[\mathrm{PbF}_{4}^{2-}\right]} \\
=\left[\mathrm{Pb}^{2+}\right]+\mathrm{K}_{1}\left[\mathrm{~Pb}^{2+}\right]\left[\mathrm{F}^{-}\right]+\mathrm{K}_{2}\left[\mathrm{~Pb}^{2+}\right]\left[\mathrm{F}^{-}\right]^{2} \\
+\mathrm{K}_{3}\left[\mathrm{~Pb}^{2+}\right]\left[\mathrm{F}^{-}\right]^{3}+\mathrm{K}_{4}\left[\mathrm{~Pb}^{2+}\right]\left[\mathrm{F}^{-}\right]^{4} \\
{\left[\mathrm{~Pb}^{2+}\right]\left(1+\mathrm{K}_{1}\left[\mathrm{~F}^{-}\right]+\mathrm{K}_{2}\left[\mathrm{~F}^{-}\right]^{2}+\mathrm{K}_{3}\left[\mathrm{~F}^{-}\right]^{3}+\mathrm{K}_{4}\left[\mathrm{~F}^{-}\right]^{4}\right)}
\end{gathered}
$$

The total fluoride ion concentration $\left[\mathrm{F}^{-}\right]_{\mathrm{T}}$ can be represented by:

$$
\begin{aligned}
& {\left[\mathrm{F}^{-}\right]_{\mathrm{T}}=\left[\mathrm{F}^{-}\right]+[\mathrm{HF}]+\left[\mathrm{HF}_{2}^{-}\right]+[}\left.\mathrm{PbF}^{+}\right]+2\left[\mathrm{PbF}_{2}\right] \\
&+3\left[\mathrm{PbF}_{3}^{-}\right]+4\left[\mathrm{PbF}_{4}^{2-}\right] \\
&=\left[\mathrm{F}^{-}\right]\left(1+\mathrm{K}_{\mathrm{HF}}\left[\mathrm{H}^{+}\right]+\mathrm{K}_{\mathrm{HF}} \mathrm{K}_{\mathrm{HF}_{2}}\left[\mathrm{H}^{+}\right]\left[\mathrm{F}^{-}\right]\right)+\left[\mathrm{PbF}^{+}\right] \\
&+2\left[\mathrm{PbF}_{2}\right]+3\left[\mathrm{PbF}_{3}^{-}\right]+4\left[\mathrm{PbF}_{4}^{2-}\right]
\end{aligned}
$$

In aqueous solution, reactions of hydrogen fluoride are included as follows ${ }^{27}$ :

$$
\begin{gathered}
\mathrm{H}^{+}+\mathrm{F}^{-}=\mathrm{HF} ; \mathrm{K}_{\mathrm{HF}}=1.5 \times 10^{3} \\
\mathrm{HF}+\mathrm{F}^{-}=\mathrm{HF}_{2}^{-} ; \mathrm{K}_{\mathrm{HF}_{2}^{-}}=3.9
\end{gathered}
$$

In general, waste acid in lead smelter is neutralized. The $\mathrm{pH}$ value of the waste acid will rise to 5-7. Because the hydrogen fluoride ion concentration $\left[\mathrm{HF}_{2}^{-}\right]$is very low, it is usually to be neglected in concrete calculation.

At $25^{\circ} \mathrm{C}$, we can obtain the distribution fraction of fluoride ion and hydrogen fluoride in the aqueous solution as shown in Fig. 2:

Fig. 1 shows the distribution fraction diagram $(\delta)$ of fluoride ion and hydrogen fluoride at different $\mathrm{pH}$. When the solutions have $\mathrm{pH}$ values greater than 5-7, hydrogen fluoride were almost dissociated. Under this condition, we can also ignore the coordination of lead ion and hydroxide ion when the concentration of lead ion is no more than $0.05 \mathrm{~mol} \mathrm{~L}^{-1}$.

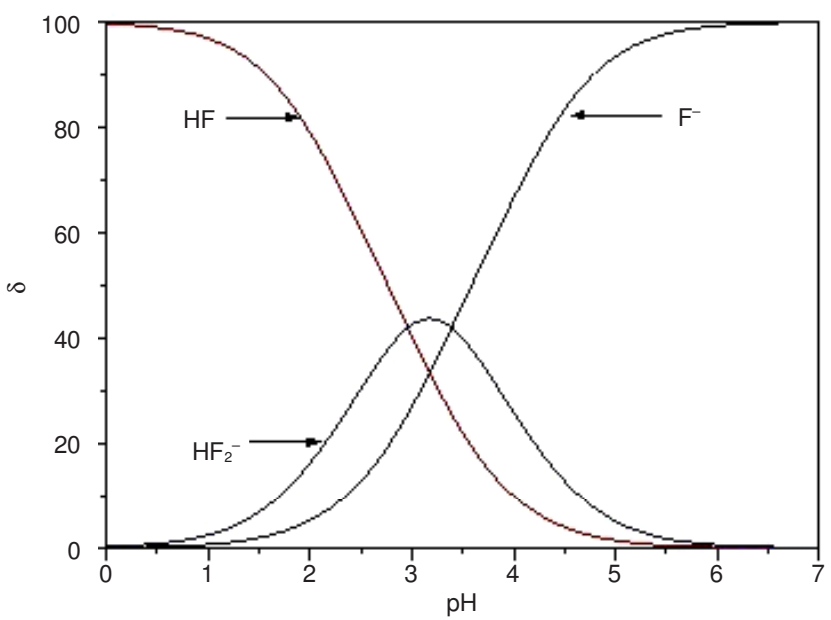

Fig. 1. Relationships between distribution of fluoride and $\mathrm{pH}$ value

Eqns. 1 and 2 are of great significance in analyzing the equilibrium relationships of the complex system under consideration. The controllable quantities $[\mathrm{Pb}]_{\mathrm{T}}$ and $[\mathrm{F}]_{\mathrm{T}}$ can be linked together with the equilibrium variables $\left[\mathrm{Pb}^{2+}\right]$ and $\left[\mathrm{F}^{-}\right]$, respectively. At the same time, according to the principle of simultaneous equilibrium with the various lead ion species in solution, there is only one electrode potential being possibly measured, that is $\mathrm{E}_{\mathrm{Pb}^{2+} / \mathrm{Pb}}=\mathrm{E}_{\mathrm{PbF}^{+} / \mathrm{Pb}}=\mathrm{E}_{\mathrm{PbF}_{2(\mathrm{aq})} / \mathrm{Pb}}=\ldots$ $=\mathrm{E}_{\mathrm{Pb}_{\mathrm{n}}^{2-\mathrm{n}} / \mathrm{Pb}}$, the value of which can be calculated by the following expression:

$$
\begin{aligned}
& \mathrm{E}_{\mathrm{Pb}^{2+} / \mathrm{Pb}}=\mathrm{E}_{\mathrm{Pb}^{2+} / \mathrm{Pb}}^{0} \\
+ & \frac{2.303 \mathrm{RT}}{\mathrm{nF}} \log \frac{[\mathrm{Pb}]_{\mathrm{T}}}{1+\beta_{1}\left[\mathrm{~F}^{-}\right]+\beta_{2}\left[\mathrm{~F}^{-}\right]^{2}+\beta_{3}\left[\mathrm{~F}^{-}\right]^{3}+\beta_{4}\left[\mathrm{~F}^{-}\right]^{4}}
\end{aligned}
$$

Eqn. 3 shows that at a given temperature and a know value of $[\mathrm{Pb}]_{\mathrm{T}}$ the equilibrium electrode potential of solid lead decreases as $\left[\mathrm{F}^{-}\right]$increases. When the fluoride ion concentration is lower, the concentration of total lead in solution and the fluoride ion concentration relationship is shown in Fig. 2:

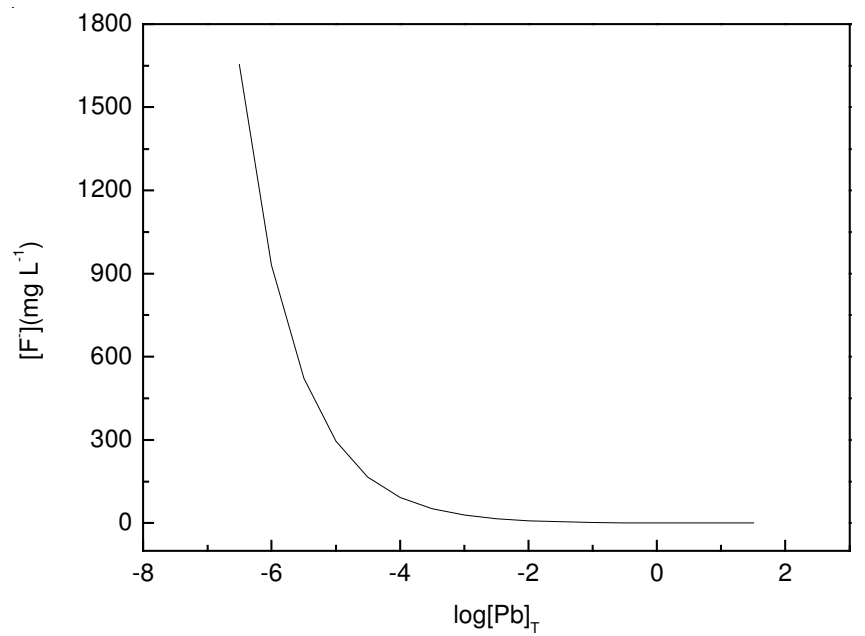

Fig. 2. Relationship of $[\mathrm{Pb}]_{\mathrm{T}}$ and $\left[\mathrm{F}^{-}\right]$at $25^{\circ} \mathrm{C}$

However, on the one hand, the product of $\left[\mathrm{Pb}^{2+}\right]$ and $\left[\mathrm{F}^{-}\right]^{2}$ in solution is greater than the solubility product $\mathrm{K}_{\mathrm{sp}}$ at a given temperature when $\left[\mathrm{F}^{-}\right]$increases to a certain limit. As a result, the precipitation of solid lead fluoride occurs. On the other hand, the product of $\left[\mathrm{Pb}^{2+}\right]$ and $\left[\mathrm{F}^{-}\right]^{2}$ is smaller than $\mathrm{K}_{\mathrm{sp}}$ if the concentration of fluoride ion $\left[\mathrm{F}^{-}\right]$in solution continues to increase. Then, the lead fluoride will be dissolved. This means that in the lead-fluoride ion-water system the sparingly soluble salt $\mathrm{PbF}_{2(\mathrm{~s})}$ can stably exist only within a certain limit of fluoride ion concentration. The limit of fluoride ion concentration for the stability region of solid lead fluoride can be determined from the $\mathrm{E}-\log \left[\mathrm{F}^{-}\right]$diagram for the lead-fluoride ion-water system. For this purpose, we use eqn. 1 and the following eqn. 4 to calculate the electrode potential dependence on $\log \left[\mathrm{F}^{-}\right]$ at a given temperature and a given total concentration of lead $[\mathrm{Pb}]_{\mathrm{T}}$.

$$
\mathrm{E}_{\mathrm{PbF}_{2(\mathrm{~s})} / \mathrm{Pb}}=\mathrm{E}_{\mathrm{PbF}_{2(\mathrm{~s})} / \mathrm{Pb}}^{0}+\frac{2.303 \mathrm{RT}}{\mathrm{nF}} \log \left[\mathrm{F}^{-}\right]
$$

Fig. 3 shows that the sparingly soluble salt $\mathrm{PbF}_{2}$ (s) can stably exist only within a certain limit of area under the given conditions. In Fig. 3, the area within the bounds of the equilibrium fluoride ion concentration located at the points $\alpha$ and 


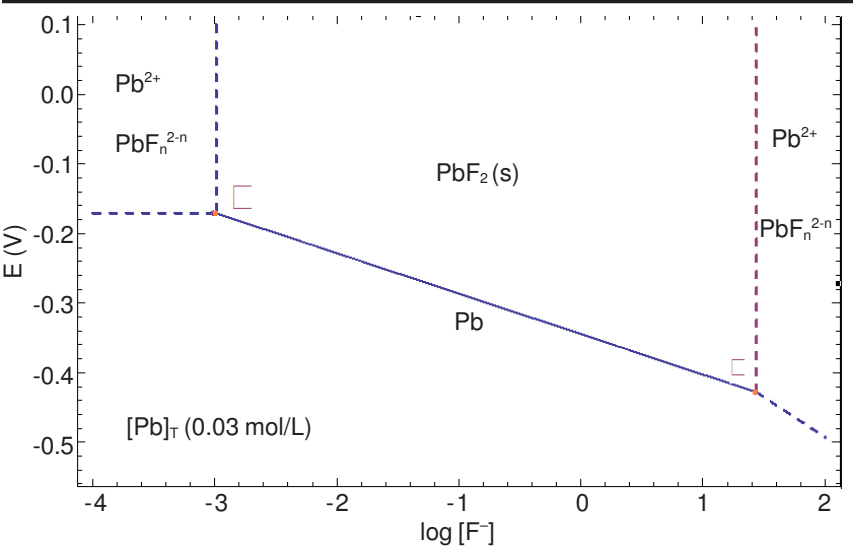

Fig. 3. E-log $\left[\mathrm{F}^{-}\right]$diagram of lead-fluoride ion-water system under $[\mathrm{Pb}]_{\mathrm{T}}=$ $0.03 \mathrm{~mol} \mathrm{~L}^{-1}$ at $25^{\circ} \mathrm{C}$

$\beta$ will be the stability region of solid lead fluoride at the given conditions.

Fig. 4 shows the E-log $\left[\mathrm{F}^{-}\right]$diagram for the lead-fluoride ion-water system at different $[\mathrm{Pb}]_{\mathrm{T}}$ at $25{ }^{\circ} \mathrm{C}$. From Fig. 4, it can be seen the different $[\mathrm{Pb}]_{\mathrm{T}}$ corresponds to the different points $\alpha$ and $\beta$. The stability region of lead fluoride enlarges with increase of $[\mathrm{Pb}]_{\mathrm{T}}$. On the contrary, it becomes smaller.

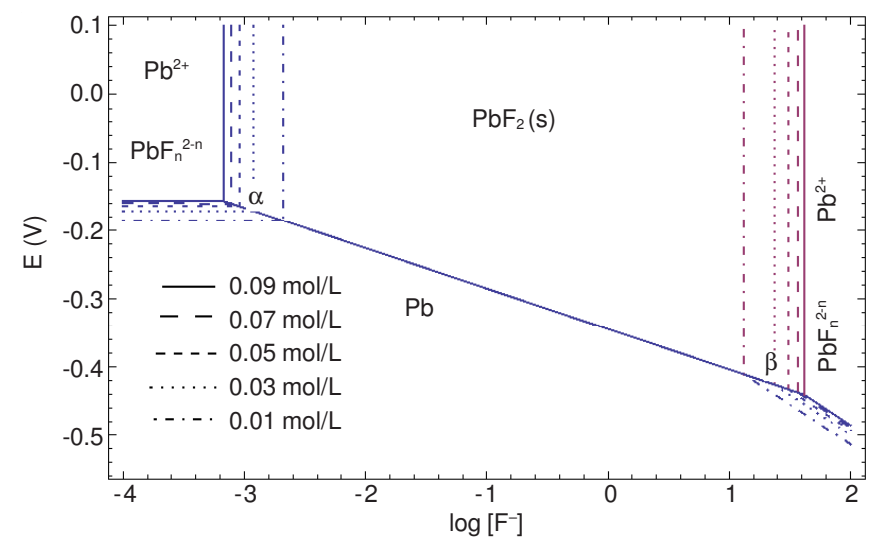

Fig. 4. E-log $\left[\mathrm{F}^{-}\right]$diagram of lead-fluoride ion-water system at different $[\mathrm{Pb}]_{\mathrm{T}}$ at $25^{\circ} \mathrm{C}$

The equilibrium concentrations of fluoride ion corresponding to those as shown by points $\alpha$ and $\beta$ in Fig. 4 can be determined by the following equation:

$$
\begin{aligned}
\mathrm{K}_{\mathrm{sp}}+\mathrm{K}_{\mathrm{sp}} & \mathrm{K}_{1}\left[\mathrm{Cl}^{-}\right]+\left(\mathrm{K}_{\mathrm{sp}} \mathrm{K}_{2}-[\mathrm{Pb}]_{\mathrm{T}}\right)\left[\mathrm{Cl}^{-}\right]^{2} \\
& +\mathrm{K}_{\mathrm{sp}} \mathrm{K}_{3}\left[\mathrm{Cl}^{-}\right]^{3}+\mathrm{K}_{\mathrm{sp}} \mathrm{K}_{4}\left[\mathrm{Cl}^{-}\right]^{4}=0
\end{aligned}
$$

which is derived from the relationship that the electrode potentials $\mathrm{E}_{\mathrm{Pb}^{2+} / \mathrm{Pb}}$ and $\mathrm{E}_{\mathrm{PbF}_{2(\mathrm{aq})} / \mathrm{Pb}}$ at either point $\alpha$ or $\beta$ are equal to each other.

Solubility product of lead fluoride is $2.7 \times 10^{-8}$ at $25^{\circ} \mathrm{C}$. Thus, in compliance with eqn. 5 together with eqns. 1 and 2 , the total concentration of fluoride ion $\left[\mathrm{F}^{-}\right]_{\mathrm{T}}$ corresponds to the total concentration of fluoride ion $[\mathrm{Pb}]_{\mathrm{T}}$ at the points $\alpha$ and $\beta$ can be calculated. Based on these data, the solubility curve of lead fluoride at $25^{\circ} \mathrm{C}$ is shown in Fig. 5.

The solubility curve has a minimum point. The values of $[\mathrm{Pb}]_{\mathrm{T}}$ and $[\mathrm{F}]_{\mathrm{T}}$ at this minimum point is really in agreement with the value when the stability region of lead fluoride on the

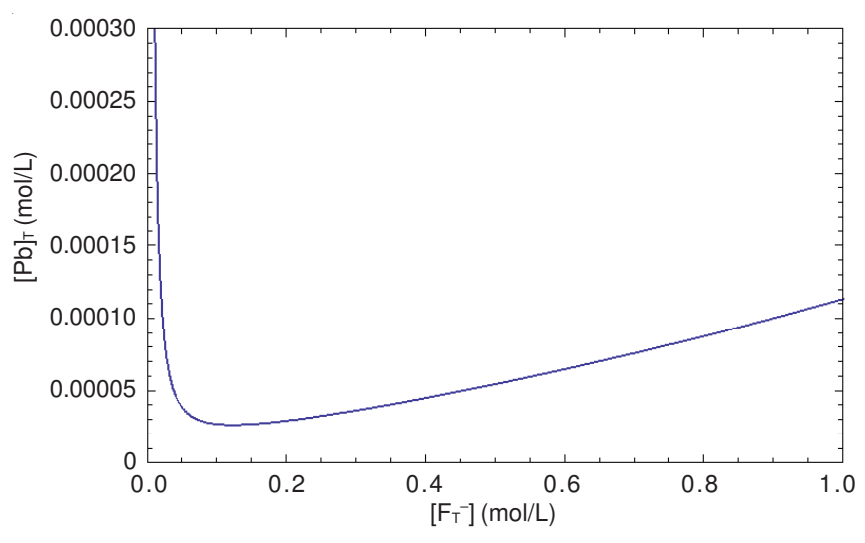

Fig. 5. Solubility curve of lead fluoride at $25^{\circ} \mathrm{C}$

E-log $\left[\mathrm{F}^{-}\right]$diagram has just disappeared. This value can be calculated in the following manner:

$$
[\mathrm{Pb}]_{\mathrm{T}}=\frac{\mathrm{K}_{\mathrm{sp}}\left(1+\beta_{1}\left[\mathrm{~F}^{-}\right]+\beta_{2}\left[\mathrm{~F}^{-}\right]^{2}+\beta_{3}\left[\mathrm{~F}^{-}\right]^{3}+\beta_{4}\left[\mathrm{~F}^{-}\right]^{4}\right)}{\left[\mathrm{F}^{-}\right]^{2}}
$$

Then differentiating the function $[\mathrm{Pb}]\left[_{\mathrm{T}}=\mathrm{f}\left(\left[\mathrm{Cl}^{-}\right]\right)\right.$from eqn. 6 and setting the result equal to zero. We get the following equation after rearrangement

$$
2 \beta_{4}\left[\mathrm{~F}^{-}\right]^{4}+\beta_{3}\left[\mathrm{~F}^{-}\right]^{3}-\beta_{1}\left[\mathrm{~F}^{-}\right]-2=0
$$

Using the value of $\left[\mathrm{F}^{-}\right]$calculated from eqn. 7 , we obtain corresponding value of $\left[\mathrm{Pb}^{2+}\right]$ according to the relation of $\left[\mathrm{Pb}^{2+}\right]=\frac{\mathrm{K}_{\mathrm{sp}}}{\left[\mathrm{F}^{-}\right]^{2}}$. Finally, with the aid of eqns. 1 and 2, we can get the corresponding total lead ions concentrations and total fluoride ions concentration at the minimum point on the solubility curves.

To achieve the objective of fluoride ion removal, we can adjust the concentration of total lead to control the total fluoride concentration in the solution. Table-2 shows the relationship of $\left[\mathrm{Pb}^{2+}\right]_{\mathrm{T}}$ and $[\mathrm{F}]_{\mathrm{T}}$ in the solution.

\begin{tabular}{ccc} 
TABLE-2 \\
\multicolumn{3}{c}{$\begin{array}{c}\left.\text { RELATIONSHIP OF [Pb }{ }^{2+}\right]_{\mathrm{T}},\left[\mathrm{F}^{-}\right] \text {AND }[\mathrm{F}]_{\mathrm{T}} \\
\text { IN AQUEOUS SOLUTION }\end{array}$} \\
\hline$\left[\mathrm{Pb}^{2+}\right]_{\mathrm{T}}\left(\mathrm{mol} \mathrm{L}^{-1}\right)$ & {$[\mathrm{F}]\left(\mathrm{mol} \mathrm{L}^{-1}\right)$} & {$\left[\mathrm{F}_{\mathrm{T}}\left(\mathrm{mol} \mathrm{L}^{-1}\right)\right.$} \\
\hline 0.0005 & $8.22 \times 10^{-3}$ & $8.45 \times 10^{-3}$ \\
0.0050 & $2.40 \times 10^{-3}$ & $2.75 \times 10^{-3}$ \\
0.0080 & $1.88 \times 10^{-3}$ & $2.28 \times 10^{-3}$ \\
0.0100 & $1.68 \times 10^{-3}$ & $2.14 \times 10^{-3}$ \\
0.0120 & $1.53 \times 10^{-3}$ & $2.04 \times 10^{-3}$ \\
\hline
\end{tabular}

Significance of thermodynamic analysis on the experiment and production: The total fluoride concentration is up to $3-5 \mathrm{~g} \mathrm{~L}^{-1}$ in waste acid in some of the lead smelter, thus lead ion to fluoride removal has prominent effect. We can use containing lead oxide materials such as blast furnace, lead ash reducing fluoride ion concentration in solution. Using the appropriate concentration of lead ion, the fluoride ions in the solution concentration will be less than $40 \mathrm{mg} \mathrm{L}^{-1}$. The precipitation residue can be returned lead smelting system, which avoids the shortcoming of the traditional method producing a lot of waste residue. 
At room temperature, $20 \mathrm{~mL}$ of acetic acid, a suitable amount of water and $3 \mathrm{~kg}$ lead ash were mixed with agitation speed of $300 \mathrm{rpm}$. Then, $10 \mathrm{~L}$ waste acid was added the serofluid of the lead ash with the velocity of flow of $50 \mathrm{~mL}$ $\min ^{-1}$. Reaction was ended when the $\mathrm{pH}$ value increased to 6-7. After the liquid-solid separation, the residue was sent to smelter for pyrometallurgical treatment. Through the above approaches and measures, the sulfuric acid of the waste acid removal ratio exceeded $95 \%$, the fluoride removal ratio exceeded $90 \%$.

\section{Conclusion}

- The thermodynamic analysis shows that the materials containing lead oxide can effectively remove the fluoride in the fluoride solution. Lead ion concentration is adjusted by acetic acid at room temperature. When the $\mathrm{pH}$ value is about $6-7$, the fluoride in the solution can be remove to less than 40 $\mathrm{mg} \mathrm{L} \mathrm{L}^{-1}$.

- In lead smelter, lead dust can be used as precipitant to remove the fluoride in waste acid. Under appropriate conditions, the removal rate of fluoride is up to $90 \%$ in the waste acid.

\section{ACKNOWLEDGEMENTS}

This work is supported financially by Major National Science and Technology Programs of China (No. 2010ZX07212008), Scientific and Technological Commission of Hunan Province of China (No. 2012SK3112).

\section{REFERENCES}

1. A. Bhatnagar, E. Kumar and M. Sillanpää, Chem. Eng. J., 171, 811 (2011).

2. J. Dron and A. Dodi, J. Hazard. Mater., 190, 300 (2011).

3. C.T. Benatti, C.R.G. Tavares and E. Lenzi, J. Environ. Manage., 90, 504 (2009).

4. R. Malaisamy, A. Talla-Nwafo and K.L. Jones, Sep. Purif. Technol., 77, 367 (2011)
5. Y.C. Lee, E.J. Kim, H.J. Shin, M. Choi and J.W. Yang, J. Ind. Eng. Chem., 18, 871 (2012).

6. B.D. Turner, P. Binning and S.L.S. Stipp, Environ. Sci. Technol., 39, 9561 (2005).

7. E. Alkan, E. Kir and L. Oksuz, Sep. Purif. Technol., 61, 455 (2008).

8. N.C. Lu and J.C. Liu, Sep. Purif. Technol., 74, 329 (2010).

9. S.K. Nath, S. Bordoloi and R.K. Dutta, J. Fluorine Chem., 132, 19 (2011).

10. S.K. Adhikary, U.K. Tipnis, W.P. Harkare and K.P. Govindan, Desalination, 71, 301 (1989).

11. M. Behbahani, M.R.A. Moghaddam and M. Arami, Desalination, 271, 209 (2011).

12. M.M. Emamjomeh and M. Sivakumar, J. Environ. Manage., 90, 1204 (2009).

13. H. Lounici, L. Addour, D. Belhocine, H. Grib, S. Nicolas and B. Bariou, Desalination, 114, 241 (1997).

14. T. Hiemstra and W.H.V. Riemsdijk, J. Colloid Interf. Sci., 225, 94 (2000).

15. Y.L. Tang, X.H. Guan, J.M. Wang, N. Gao, M.R. Mcphail and C.C. Chusuei, J. Hazard. Mater., 171, 774 (2009).

16. M. Mohapatra, K. Rout, P. Singh, S. Anand, S. Layek, H.C. Verma and B.K. Mishra, J. Hazard. Mater., 186, 1751 (2011).

17. M.F.A. Taleb, G.A. Mahmoud, S.M. Elsigeny and E.-S.A. Hegazy, J. Hazard. Mater, 159, 372 (2008).

18. I.B. Solangi, S. Memon and M.I. Bhanger, J. Hazard. Mater., 171, 815 (2009).

19. S. Meenakshi and N. Viswanathan, J. Colloid Interf. Sci., 308, 438 (2007).

20. K. Vaaramaa and J. Lehto, Desalination, 155, 157 (2003).

21. G.H. Zhang, Y. Gao, Y. Zhang and P. Gu, Desalination, 177, 143 (2005).

22. P. Sehn, Desalination, 223, 73 (2008).

23. A. Tor, J. Hazard. Mater., 141, 814 (2007).

24. K. Hu and J.M. Dickson, J. Membr. Sci., 279, 529 (2006).

25. E. Alkan, E. Kir and L. Oksuz, Sep. Purif. Technol., 61, 455 (2008).

26. Chemical Analytic Handbook,Central South China Institute of Mining and Metallurgy, Science Press, Beijing, pp. 126-127 (1998).

27. A.E. Martell and R.M. Smith, Critical Stability Constants, Plenum Press, New York, p. 415 (1974). 